\title{
Study on Mandatory Norms of Company Law
}

\author{
Haibo Yao \\ School of Business Administration, Jincheng College of Sichuan \\ University, Chengdu, Sichuan, 611731
}

\begin{abstract}
With the development of the society and economy, the company has become the most important market main body in modern social economic activities, and the Company Law is becoming more and more important. There is no uniform standard on how to distinguish between mandatory and arbitrary norms. How to divide, configure and apply these two kinds of norms in company law has become the key of legislative, law enforcement, judicial and other activities. This paper chooses the mandatory standard of company law as the object of study, using economic analysis, system analysis, historical analysis, empirical analysis and other methods, from the analysis of legal norms of the most basic concept of the law, the company law mandatory norms more comprehensive Analysis, to solve specific problems in practice.
\end{abstract}

Keywords: Company, Law Construction, Mandatory specification

\section{Introduction}

Among the many issues relating to the law, there are always enough to constitute the cornerstone of legal theory; which includes both the "macro" and "micro" issues, if allowed us to apply such a line roughly. "What is law" has been repeatedly suggested by Hart as an "enduring problem", although it has proved more successful than the goals pursued by John Austin and Hans Kelsen Excellent, but I am afraid will never be able to achieve the theoretical perfection, future generations are also constantly go beyond or improve his theory. Another example is "what is the right to expect," such issues, some scholars call it "rights of the embryo" or "shadow of the right projection", some called "sub-class rights" or "integrity rights" Have their own reasons. These two examples are given only 
to illustrate two aspects. First, although we know the legal system has been building a high-rise buildings, but a lot of basic issues are still worthy of our attention. Second, there is no end to the study of these fundamental factors, but we can limit the research to infinity. Based on this consideration, this paper aims to identify a basic problem: "mandatory norms." However, even if only from a legal point of view, the "peremptory norm" is still a rich area of content: what is the mandatory norms, what is its definition; mandatory norms and other types of norms fundamental difference; What characteristics it has, can be divided into several types; whether the peremptory norms between the different legal departments have the same characteristics; These are questionable questions. As a jurisprudence paper rather than an encyclopedia of books, this paper hopes to minimize the scope of the discussion. Narrowing the scope has the two main ways: the selection of mandatory norms related to an aspect of discussion, as well as the source of the peremptory norms is confined to a sector law. Through the "Introduction" part of this article, I will show their concern about the areas of mandatory norms.

\section{The Legitimacy of the Existence of Peremptory Norms of Company Law}

In the corporate sphere, the separation of ownership from managerial authority has been a widespread phenomenon in that, on the one hand, shareholders are limited or only willing to participate in corporate governance, and in many cases the shareholders are analogous to the beneficiaries of the trust relationship On the other hand, the company's management almost completely control the company's resources and make decisions, shareholders and the company's management, small shareholders and large shareholders, there is a serious information asymmetry. Therefore, in order to protect the investors have full right to know, there is the need to introduce national coercive power.

Public goods are relative to private property, and "it is a product of this kind that does not lead to an increase in cost when a person is added to it (their consumption is non-competitive), and the exclusion of any individual of the share to spend a huge cost (they are non-exclusive). The noncompetitive and nonexclusive nature of public goods causes the competitors in the market to have a free-rider mentality, that is, they can not solve their own problems, others will solve them, and they can also obtain benefits or obtain commodities in passing Without incurring any costs. In this case, there must be mandatory norms to maintain the standard terms as the role of public goods.

The reason why a behavior can be incorporated into the legal adjustment of the track, because there are several basic features: First, involving other sex. This is the behavior of the main features of the law regulation, "involving him" means that the content and consequences of behavior will affect other people in society; the second is the interest that the individual's behavior may involve between the interests of others Relationship, that is, the act itself may have an impact on the 
freedom, rights or interests of others. The act of giving rise to an effect on the interests of others, either as an act or as an omission, requires that a person not only be affected by others in his or her actions, but also produce the same result by his inaction, and in both cases It is justified for them to be accountable to them for the damage. "Thus, his interest-related behavior is always subject to legal control, and, in general, the greater the involvement of other factors in the conduct of the act, The higher the degree. The reason why the law intervenes in this kind of behavior is to prevent the harm to the interests of others, prevent the conflict of the behavior of the related people, and maintain the stability of the basic social order. In the system of the company there are a lot of interests involved in his behavior, such as the interests of the company's creditors are often damaged, so the state should develop a mandatory standard.

\section{Scope of Compulsory Regulation of Company Law}

The behavior of the company is equal to the interests of shareholders in the exercise of the interests of the market behavior. As Aristotle said, "the power of the people who have the tendency to abuse power, this is the ancient truth is not easy." Abuse of rights means that the right of the owner are to exercise the right to violate the law to give the purpose of the right and the law does not recognize its right to exercise the behavior of that. The dominant position in the company tends to use its dominant position to oppress other subjects. Therefore, we need the intervention of the public power of the state, limit the abuse of the right of the main body to protect the interests of other subjects.

Logically, the phenomenon of stakeholder with the company, but as a term, "Stakeholders (Stakeholders)" is in the 20th century, 60 years before the emergence of. But for those who are stakeholders, the academic community has not formed a consensus, economist Mitchell (Mitchell) summed up more than 20 kinds of points of view. To sum up, there are three main categories: the broadest concept of extension: all can affect business activities or be affected by corporate activities are individuals or groups of stakeholders; extension of the narrow concept: all companies directly related to the person or group Is the stakeholder; the narrowest concept of extension: only in the company under the "bet" person or group is the stakeholders, that is, only in the company into the special assets of the person or group is the stakeholder. The first two categories of the definition of stakeholder broad, similar to the company's social responsibility theory, the new company law also provides the company's social responsibility, the company should bear the corresponding social responsibility is the basis for the protection of stakeholders. 


\section{Legislation Proposals on Mandatory Norms of Company Law in China}

There are a lot of arbitrary norms, it can be said that the organic composition of the two norms, arbitrary norms reflect the nature of the private law of the company law, the mandatory norms of the rules of the company's legal obligations, For the arbitrary specification escort. The new company law is based on deregulation, respect for the legislative objectives of the autonomy of shareholders, the re-characterization of the mandatory norms and arbitrary norms of the original law of the company is too mandatory, and arbitrariness, the law rarely show arbitrary, Arrangements, the addition of a number of arbitrary provisions, but also some of the original mandatory provisions to arbitrary terms. As the private law of the company law, is based on individual-based philosophy and legislative guiding ideology, the pursuit of personal freedom of expression and personal interests of the greatest degree of realization. Autonomy is the assumption of rational economic man, I believe that everyone will make the most beneficial to their own decisions, and through the free trade, self-government and self-government is the most important principle of autonomy, Limited resources to produce the greatest benefits at the lowest cost, the overall public welfare is also natural to reach. "Therefore, the ideal state of the company law is to achieve corporate autonomy, corporate autonomy is private law principle embodied in the company system. The external manifestation of company autonomy is that the company has an independent personality, the internal performance of which is that the company can formulate the articles of association as the self-management rules to adjust the internal organizational relations and operating behaviors of the company.

The new company law stipulates the company should bear the corresponding social responsibility, but the connotation and extension of social responsibility is extremely broad, the new company law for what social responsibility, including what content, in violation of this mandatory standard will lead to what consequences, Is not clear. It is therefore necessary to emphasize its appropriateness in the understanding and use of this concept. In the United States, there is a different view on corporate social responsibility, and if directors are asked to be held accountable for too many "interest groups", the result can only be that they are not accountable to either party. Moreover, those who deal with the company, such as creditors, customers, employees, etc. can be agreed by the contract, and even threatened to interrupt and the way business relationships to protect themselves. But the shareholders are unable to achieve self-protection, because their investment has been "precipitated" in the company, and can not be withdrawn.

The legislation of our country has a certain degree of confusion of legal terms. Judging only from the expression of the normative nature of many legal provisions are often inaccurate, and even come to the opposite conclusion. "Accuracy is the soul of the legislative language and life, and therefore the legislative language of the most basic requirements," the only way to truly express the intention of legislators, so that the law applicable to accurate 
understanding and compliance. However, there are many problems in the choice of legislative language in the Chinese company law.

The peremptory norm in company law is automatically applied to the relevant parties and is not subject to any change or refusal to apply. In any case, any change or refusal of such specification shall be deemed to be contrary to the provisions of the Company Law. In a certain sense, the so-called party violated the company law mainly refers to the parties violate the mandatory norms. Therefore, the accurate allocation, definition and application of the peremptory norms of company law are of great significance to China's legislation and judicial practice, and need to be further improved.

\section{Conclusion}

Company law is a combination of autonomy and coercion, the mandatory manifestation of Company law as a mandatory norm, and the existence of mandatory norms have their legitimacy and legitimacy. According to the basic principles of legal norms, whether the application of peremptory norms or arbitrary norms of legal consequences are different, mandatory norms are often accompanied by legal sanctions, thus confirming the existence of mandatory norms in the judicial practice is very important. In the separation of mandatory norms and arbitrary norms should be taken into account the nature of the company, the nature of the specification itself, applicable to internal or external to the company and other factors, and under the guidance of these principles of the classification of mandatory peremptory norms Of the general configuration areas of the system comb.

\section{References}

[1] Hu Peiyu.Judicial Recognition of Compulsory Regulations of Company Law [J] .Economic Economics, 7(1), pp. 12-35, 2011

[2] Zhang Yunlun. Compulsive norms apply to the company's resolution invalid legal economic analysis [J]. The Age of Tomorrow, 3(6), pp. 21-25, 2015

[3] Song Shanghua. The Legislative Consideration of Compulsive Norms of Companies [J]. Journal of Shijiazhuang Railway Institute, 8(3), pp. 102-105, 2008

[4] CHEN Peng-hui, ZHONG Li-hong, ZHOU Yin-chun.Comparative Analysis of Mandatory Norms of Commercial Law and Mandatory Norms of Economic Law [J] .Market Modernization, 6(8), pp. 54-65, 2013

[5] Wang Shumeng.Comparative analysis of mandatory norms of commercial law and mandatory norms of economic law [J] .Market Modernization, 29(8), pp. 6176,2014 